\title{
Developing the Early Warning System for identification of students at risk of dropping out using a collaborative action research process ${ }^{1,2}$
}

Olja Jovanović ${ }^{3}$

University of Belgrade, Faculty of Philosophy

\section{Ljiljana Plazinić}

University of Belgrade, Teacher Education Faculty

\section{Jelena Joksimović ${ }^{4}$}

University of Belgrade, Faculty of Philosophy

Jovan Komlenac

General high school "Sava Šumanovic", Šid

\section{Ana Pešikan}

University of Belgrade, Faculty of Philosophy

The paper presents findings of collaborative action research aimed at exploring and describing the process of the development of the early warning system for identification of students at risk of dropping (EWS). The study has been conducted in collaboration between practitioners from five vocational agriculture and food science schools and research team with expertise in the field of educational psychology. Study employed one cycle of collaborative action research including planning, acting, observing, reflecting and revising phase. During the planning and action phase, Instrument for identification of students at risk of dropping out has been developed and implemented on the sample of 485 first grade students.

1 This research was supported in the framework of the European Commission proposal "Implementation of the European strategic objectives in education and training" (EACEA/04/13) under the Lifelong Learning Programme.

2 Parts of the findings were presented at 23rd Empirical Studies in Psychology (EIP 2017) conference, Belgrade, Serbia.

3 olja.jovanovic@f.bg.ac.rs

$4 \quad$ PhD student 
The collected data has been used to highlight the students who are beginning to exhibit warning signs that could become obstacles to graduation, as well as to craft meaningful prevention and intervention measures. Observations regarding the implementation of proposed methodology and reflections on collected data and ongoing processes have been systematically recorded through regular monthly meetings between researchers and practitioners. Analysis of 73 documents, collected during observation and reflection phase, resulted in 18 categories, grouped into two broad themes: pitfalls and strengths of EWS. Based on the findings, the methodology for identification of students at risk was revised to fit the needs and strengths of the specific school. The study offers valuable lessons regarding development of EWS through researchers-practitioners collaboration.

Key words: school dropout, early warning system, students at risk of dropping out, collaborative action research.

\section{Why is there such an interest in dropout?}

Reducing the dropout rate has become a concern of many national policies, particularly in the developed countries. The issue has an enormous importance both from the individual or the institutional and the national perspective and has long been viewed as a serious educational and social problem. By leaving school prior to completion, most dropouts have educational disadvantages that severely limit their economic and social wellbeing throughout their adult lives. The individual consequences lead to social costs (Rumberger, 1987, 103). Research has shown that students who dropped out of school are more likely to have health problems, get involved in criminal activities, become employed with lower income jobs, and become more dependent on welfare and other public assistance programs (e.g., Alexander, Entwisle \& Horsey, 1997).

In the times when economy moves toward higher-skilled labour force, school dropouts will have fewer chances to survive economically and take care of themselves, their families and community. The students from poor and low-income households and from socially disadvantaged groups are generally at greater risk of school dropout (Levin, 1986; Rosenthal, 1998; Rumberger, 2001). The disproportionate rates of exclusion among some groups reflect the long-standing patterns of social inequality within society. Moreover, the importance of the dropout issue is apparent when one takes a closer look at different world agendas (e.g. Millennium Developmental Goals, Laeken's indicators, Education for All, Sustainable Development Goals), particularly those that are linked with poverty reduction measures.

In line with global trends, dropout has become a topic of great interest in Serbia in recent years. Namely, in spite of the fact that universal, compulsory and free primary education has been provided by the state since 1958, still as much as one third of the population (34.44\%) does not have any professional qualifications (Statistical Office of the Republic of Serbia, 2011; Pešikan, 
2016). According to experts' analyses, the total dropout rate for primary education is between 10 and $15 \%$ of an age group (Strategy of education development in Serbia 2020, 2012). Dropout is significantly higher among children from vulnerable groups, primarily among the students from rural areas and Roma children (Statistical Office of the Republic of Serbia \& UNICEF, 2014; Jovanović et al., 2016). However, the data related to dropout in Serbia should be taken into consideration with caution since there have been no attempts to follow the cohorts of students over extended periods of time to establish school outcomes or events associated with students falling off the graduation path (Pešikan, 2012; Pešikan \& Ivić, 2009; Pešikan, 2015).

\section{Could early warning system be part of the solution?}

Students typically drop out of school for very different reasons (Stepanović-Ilić, Videnović \& Lazarević, 2015). However, a lot is still not known about dropout prevention strategies and interventions that make a positive difference. Different countries started recognising early warning systems (EWS) or related tools aimed at alerting teachers, schools and/or authorities to students who may be at risk of dropping out as a promising practice in combating the dropout (European Commission, 2014). In most countries, such 'systems' are integral parts of mainstream school monitoring or management systems rather than separate mechanisms or entities as such (e.g. Bulgaria, Belgium, Spain, Hungary, Ireland, Estonia, Latvia, Lithuania, Poland, Sweden, Slovenia, Slovakia). Some countries have specific systems, projects or programmes in this field (e.g. Austria, Croatia and England within the United Kingdom). These systems differ in their complexity and comprehensiveness. For example, in Croatia, the EWS practice is linked to schools' responsibility to monitor the absence of students in an 'e-register book'. If the number of absent classes increases, it is the responsibility of the school to ensure that school counsellors, management and other experts become involved, together with parents. In Austria, teachers are requested to identify the students who are underperforming and/or are unsure about their educational pathway, and these students are consequently identified as being at risk of dropping out.

The EWS for identification of students at risk of dropping out usually integrates four key steps: a) the identification of distress signals indicating the risk of dropping out of school, b) the development of instruments for monitoring the degree of presence of these signals, c) the establishment of a mechanism for alerting teachers, schools and/or authorities to students who may be at risk of dropping out, d) acting in order to prevent school dropout. Namely, the EWS rests on the premise that students show 'distress signals' for months, if not years, prior to dropping out of school (European Commission, 2014). As we have already mentioned, the first steps toward an 
effective dropout prevention strategy include tracking and analysing distress signals of dropping out and establishing significant "cut-points" on every signal of "in" and "out of risk". Cut-points are pre-determined criteria for identifying students as "on-track" for graduation, or at-risk for dropping out and schools are free to set cut-points based not only on research, but on their previous experiences. Although thresholds may seem arbitrary, this kind of quantitative data in action research is not treated as a valid and plausible truth about students (Atweh, Kemmis \& Weeks, 1998), but as a starting point for discussion on students aimed at discovering whether and to what degree the students are at risk and organising support and prevention activities for those who are prioritised by this kind of monitoring. Schools interested in using the data on hand for optimal impact need an electronic data system that includes individual student-level data that can track students over time and also allows risk factors to be assessed (Jerald, 2006). Additionally, they must be willing to share regularly updated data - and provide training in the use of that data -with dropout prevention team members, including teachers.

\section{What is the subject of the study?}

The study was a part of a larger international project entitled "Cross-sectoral cooperation focused solutions for preventing early school leaving" (CroCooS). The piloting part of the project was implemented in three European countries (Serbia, Slovenia, and Hungary) aiming to develop an institutional level early warning system (EWS) for combating dropout. In this paper, we will focus on discussing critically the development of the EWS for identification of students at risk of dropping out using collaborative action research process. Through highly contextual, participative and collaborative development of the EWS, we aimed at empowering school professionals to think over and reflect upon their practices based on systematic data collection and analysis. Moreover, we decided to design this study as collaborative action research (CAR), since we aimed to conduct research that does not talk about or come out of education but is for and inside the education (Carr \& Kemmis, 1986).

\section{Methodology}

\section{Sample}

According to Elliot (1991), one of the necessary preconditions of action research is that practitioners show motivation to initiate change and to innovate their practice. Therefore, open call for vocational schools willing to participate in the project was announced. The application form required the description of school dropout rate, the activities the school is undertaking in the field of dropout prevention and intervention, an argumentation why it is 
important for them to deal with dropout and a consent of Teacher Council for the project participation. The criteria for the selection were that dropout has been recognised as an important issue at the school level and that the school was willing to deal with this issue. Among ten schools applying for the participation in the project, five agricultural and food sciences schools were selected. In each of these schools, five members of the EWS teams were selected. Researchers/mentors with the expertise in the field of educational psychology were appointed to each team.

\section{Data collection procedure}

Collaborative action research design employing a recursive spiral of cycles that focuses on planning, acting, observing, reflecting, and revising (ZuberSkerritt, 1996) has been used. We applied one cycle of CAR approach during 16 months of project implementation.

The planning phase included problem definition, situation analysis, and the development of a strategic plan. Therefore, during the first two months of project implementation, the schools formed EWS teams consisting of five school professionals, teachers and non-teaching staff such as pedagogues, psychologists and librarians. In collaboration with mentors/researchers, these teams tried to describe as fully as possible the nature of dropout in the schools. All teams collected data on school dropout in the last five years in order to find out which students were leaving the school and under what conditions. Moreover, each EWS team prepared SWOT (StrengthsWeaknesses-Opportunities-Threats) analysis of their school regarding the issue of dropout, which helped to gain better understanding of each school's specific context (Helms \& Nixon, 2010). All these data helped us clarify the nature of the problem and develop a strategic plan how to increase school effectiveness in preventing students from dropping out.

The EWS typically uses readily available data. However, given that Serbia has not yet established education management information system, the action phase aimed at developing the data collection tool. Therefore, based on literature review (e.g. European Commission, 2013; European Commission, 2014) and consultations with practitioners, six signals of student dropout were identified and operationalised by short scales: absenteeism, decreasing achievement, repetition of academic year, low motivation, changes in behaviour and bullying. These six signals were assessed either by class teachers or by the student him/herself. The survey for class teachers aimed at gathering the data regarding socio-demographic characteristics, absenteeism, decreasing achievement, repetition of academic year, and behavioural changes in students. All these data, except behavioural changes, were readily available to class teachers since they were already routinely collected and reported at the individual level by school system. The survey for students included the scales on bullying and school motivation. 
We defined three levels of risk for each signal and for the instrument as a whole: the zero level indicates that the student is not at risk; the first level indicates a moderate risk; and the second level indicates a high level of risk. Therefore, the Instrument for identification of students at risk of dropping out (ISRD) consists of surveys for class teachers and for students which include operationalisation of six early warning signals, as well as a tool for data processing which calculates the levels of the general risk of dropping out, as well as the level of risk at each signal. The ISRD is designed to highlight the students who are beginning to exhibit warning signs that could become obstacles to graduation. Simultaneously, it provides school staff with information on students that could be used to craft effective interventions. School EWS teams, with the support of mentors/researchers, implemented the ISRD at the beginning of the school year 2015/16 and created an individuallevel dataset for the first grade students.

In order to provide evidence on how the course of action was being implemented, in the observation phase, regular monthly meetings between school EWS teams and mentors were held in participating schools. The monthly meetings continued until the end of the project, shifting the focus from monitoring the process to fostering reflection on the collected data and practitioners' experiences during the data collection period. Mentor's role was to encourage teacher's observation, enhance their reflection and empower their understanding and theorising. In this way, meetings were an opportunity for EWS team members to question the existing beliefs and practices related to dropout, speak about their implicit educational theories, as well as to explore and reconstruct them in the safe environment. After each meeting, the mentors prepared meeting reports. These included summaries of meetings, as well as anecdotal notes stemming from informal conversation with participants, near-verbatim accounts of meeting discussions, introspective accounts of one's feelings, attitudes, motives, and understandings.

Based on the collected data and the reflections on pitfalls and strengths of the process, a revision of the instrument and the procedures for its implementation were prepared.

\section{Results}

\section{The Action Phase}

\section{Instrument development}

Here we will present an operationalisation of the above mentioned six signals of dropout included in the ISRD.

Absenteeism. The class teachers are asked to record the total number of student's absences, including both excused and unexcused, during the first semester. The threshold was set taking into consideration empirical findings 
from both national (Jovanović et al., 2016) and international context (e.g. Allensworth \& Easton, 2007). Therefore, the student that has been absent from between $10 \%$ and $20 \%$ of classes is labelled as at moderate risk (level 1), while $20 \%$ or more absences is recognised as high risk (level 2).

Decreasing achievement. Deteriorating achievement is operationally presented as a change in student's average school mark during the school year (European Commission, 2014). If the student's average mark decreases between 0.5 and 1 , the student is flagged as being at the dropout risk level 1. If the average mark decreases by 1 mark or more, the student is at the dropout risk level 2.

Repetition of academic year. This indicator is assessed by class teachers who are asked if the student has taken a remedial exam and if he/she has repeated the grade. The students taking and passing a remedial exam are flagged as students at level 1 of risk, while students who repeated the grade are recognised as being at the level 2 of risk.

Low motivation. For assessing student motivation and attitudes toward school we used the Student Engagement, Motivation, \& Beliefs Survey, an open source instrument developed as a part of the Road Map Project ${ }^{5}$. The survey consists of 25 "I" statements accompanied by five-point Likert scales. The questionnaire is focused on perceived importance of schooling, student's educational aspirations, responsibility towards school tasks, trust towards teachers, persistence, and engagement in extracurricular activities. Based on the EWS teams and research team discussion, we agreed that the average score between 3.5 and 2.5 points indicated a moderate risk, while the average score of 2.5 or less should be taken as an indication of high dropout risk.

Bullying. The Adolescent Peer Relations Instrument, originally developed by Parada (2000), was used for assessing the level of bullying. It is a selfreported measure of the frequency the student has been in the role of a bully or a victim in the past 3 months. It contains 36 items accompanied by a sixpoint Likert scale - 18 items were used to measure bullying and 18 items were used to measure victimisation. According to this signal, if a student got bullied or bullied others at least once a week, he/she is considered to be at the risk level 1. If a student has been bullied or bullied others every day, he/she is flagged as the risk level 2.

Behavioural changes. The presence of behavioural changes is explored by asking class teachers to assess if there was a change in student's behaviour in the last 3 months regarding: lying, damaging property, withdrawing from social interactions, abusing drugs or alcohol, disturbing the class, stealing, fleeing home, sudden strong reactions, as well as changes like indifference, frequent engagement in conflicts, and high emotional sensitivity. If the

5 The official webpage of the Road Map Project: http://www.roadmapproject.org/. 
teacher reported change in one of these specific behaviours or reported other specific behaviour, this has been recognised as a risk level 1 indication, while risk level 2 would be if changes occurred in at least two specific behaviours.

General risk is determined taking into consideration the assessment of six signals of dropout. High general risk of dropping out (level 2) is determined in two cases: a) the student is at high risk (level 2) on any of the six signals, or b) the student is at moderate risk (level 1) on at least three signals. If the student shows moderate risk on two signals, he/she is assigned with moderate general risk of dropping out.

\section{Instrument implementation}

In the period from September to December 2015, the ISRD was used to collect quantitative data on dropout signals for 485 first grade students from five vocational agricultural schools in Serbia. A detailed sample structure is provided in Table 1.

Table 1. Description of the students' sample

\begin{tabular}{|c|c|c|c|}
\hline Category & Sub-category & \multicolumn{2}{|l|}{ Percentage } \\
\hline \multirow{2}{*}{ Gender } & Male & \multicolumn{2}{|l|}{61.5} \\
\hline & Female & \multicolumn{2}{|l|}{38.5} \\
\hline \multirow{2}{*}{$\begin{array}{l}\text { Duration of the student's } \\
\text { educational profile }\end{array}$} & three-year education & \multicolumn{2}{|l|}{22.3} \\
\hline & four-year education & \multicolumn{2}{|l|}{77.7} \\
\hline \multirow{4}{*}{ Parent's education } & Unfinished primary school & fathers 0.9 & mothers 2.5 \\
\hline & Primary school & fathers 24.1 & mothers 24.4 \\
\hline & Secondary school & fathers 67.5 & mothers 65.3 \\
\hline & College or faculty & fathers 7.2 & mothers 7.8 \\
\hline \multirow{4}{*}{ Parent's employment } & Unemployed & fathers 22.7 & mothers 31.3 \\
\hline & Employed & fathers 59 & mothers 46.2 \\
\hline & Self-employed & fathers 7.8 & mothers 7.2 \\
\hline & Unknown status & fathers 10.5 & mothers 15.3 \\
\hline \multirow{2}{*}{ Social welfare } & Using welfare & \multicolumn{2}{|l|}{5.3} \\
\hline & Don't use welfare & \multicolumn{2}{|l|}{94.7} \\
\hline \multirow{2}{*}{$\begin{array}{l}\text { Traveling distance from } \\
\text { school }\end{array}$} & Average distance $(\mathrm{km})$ & \multicolumn{2}{|l|}{33.1} \\
\hline & Greater than $4 \mathrm{~km}$ & \multicolumn{2}{|l|}{66.1} \\
\hline \multirow{5}{*}{$\begin{array}{l}\text { Student engagement in } \\
\text { extracurricular activities }\end{array}$} & Don’t participate & \multicolumn{2}{|l|}{20.2} \\
\hline & Few times a year & \multicolumn{2}{|l|}{17.4} \\
\hline & 1-2 times a month & \multicolumn{2}{|l|}{14.3} \\
\hline & $1-2$ times a week & \multicolumn{2}{|l|}{20.5} \\
\hline & 3 times a week or more & \multicolumn{2}{|l|}{27.7} \\
\hline \multirow{4}{*}{ Student's Aspirations } & I don't know & \multicolumn{2}{|l|}{22.7} \\
\hline & I'll find a job & \multicolumn{2}{|l|}{24} \\
\hline & I"ll go to college & \multicolumn{2}{|l|}{12.2} \\
\hline & I'll go to a faculty & \multicolumn{2}{|l|}{36} \\
\hline
\end{tabular}


The applied scales achieved solid metric characteristics. The Cronbach's alpha indicates high internal consistency for Low motivation $(\alpha=0.872)$, Bullying ( $\alpha=0.931)$ and Behavioural changes $(\alpha=0.971)$.

The collected data were used in the following phases of research as a starting point for the discussion regarding school dropout at the level of students, group of students and the school level. Here we will present the key results concerning the levels of risk according to the above described criteria (Table 2, the column named "Initial threshold").

Table 2. Percentage of students under the risk of dropping out based on initial thresholds and after the revisions

\begin{tabular}{l|ccc|ccc}
\hline \multirow{2}{*}{\multicolumn{1}{c|}{ Signals }} & \multicolumn{3}{c|}{ Initial threshold } & \multicolumn{3}{c}{ Modified threshold } \\
\cline { 2 - 7 } & Level 1 & Level 2 & Total & Level 1 & Level 2 & Total \\
\hline Behavioural changes & 8.9 & 4.3 & 11.2 & 8.9 & 4.3 & 13.2 \\
Decreasing achievement & $/$ & $/$ & $/$ & 37.7 & $/$ & 37.7 \\
Low motivation & 8.5 & 0.2 & 8.7 & 12.8 & 3.3 & 16.1 \\
Grade repetition & 3.5 & 3.3 & 6.8 & 3.5 & 3.3 & 6.8 \\
Absenteeism & 19.7 & 9.3 & 29 & 8.9 & 3.9 & 12.8 \\
Bullying & 13.7 & 13.7 & 27.4 & 7.2 & 4.1 & 11.3 \\
General risk & 29.4 & 26.1 & 55.5 & 19.5 & 10.6 & 30.1 \\
\hline
\end{tabular}

It seems that absenteeism and bullying are the most common signals of dropout in student sample. We were lacking the data for decreasing the achievement signal due to class teachers' resistance towards computing students' average marks before the end of the semester. Therefore, we ended up with students' marks only at one time point, at the end of semester, which prevented us from assessing the percentage of students at risk based on the initially set threshold. Our findings suggest that half of the first grade students were at some level of risk of dropping out, $29.4 \%$ students under a moderate and $26.1 \%$ students under high risk. The EWS teams used this data together with other information about the students (Table 1) to start the discussions about students at risk with other teachers, organise support and craft effective prevention and intervention activities.

At individual level, preventions and interventions were developed in the form of a personal development plan (PDP). The process included collecting more in-depth data about the student's strengths and needs for support, planning, implementing, monitoring and revising individualised support in cooperation with teachers, non-teaching staff, parents and local stakeholders. During the project, the EWS teams created PDPs ${ }^{6}$ for 28 students.

At school level, the EWS teams developed a variety of activities based on the data collected through the ISRD. For example, $51.8 \%$ of the first grade

6 We have been using a PDP that adapts the content, approach and setting, but does not change the expected achievement standards. 
students in School 4 answered that they were not sure what they would like to do after they graduate, compared to the average of $22.5 \%$ of students in other schools. This finding motivated the EWS team from this school to develop activities aimed at professional orientation of students, as well as at strengthening students' professional identity.

The implementation of the ISRD also raised awareness on the importance of documenting dropout in order to timely identify trends and prevent similar occurrences (creating a database of the signed out students, collecting more data from the parents and the student about the reasons of dropping out, summing up documentation about school actions in order to prevent the student from dropping out etc.).

The ISRD provided valuable data that were used in identifying factors leading to school dropout, as well as in developing a variety of prevention and intervention activities.

\section{The Observation and Reflection Phase}

Qualitative analysis allowed a deeper look into the issue of how the school EWS team had used the proposed methodology to mediate interactions in their communities of practice. The sample for qualitative analysis included five schools' and five mentors' final reports, 58 monthly mentor reports and five EWS teams' feedback on the usefulness of the ISRD, 73 documents in total, collected during the observation and reflection phase. Since building the EWS was a pervasive topic in the observation and reflection phase, we decided to conduct a comprehensive analysis of all the collected documents. We used an inductive thematic analysis to gain better understanding of the process of the EWS development, based on the guidelines of Braun and Clarke (2006). A comprehensive process of data coding and identification of themes was undertaken using the software for qualitative data analysis MaxQDA 11. The first step of the process involved careful reading and rereading of the data and taking notes to record patterns and ideas for codes. The second step involved a data-driven process of generating initial codes to produce a coding manual. Once the coding manual had been produced, the first researcher applied codes to each of the documents in the analysis. This was followed by the manual coding of a sample of data (four out of 73 documents) by an independent coder, to examine the accuracy of initial coding (66.7\% of agreement). Once the coding of extracts had been completed, the inconsistencies were discussed among independent coders and refinements were made until an agreement between researchers was achieved. The last step involved segmenting the coded extracts into themes. The dominant factor influencing the determination of themes was the presence of similar codes across the data set. 
The analysis of 73 documents, collected during the observation and reflection phase, resulted in 18 categories, grouped into two broad themes: 1) The pitfalls of the EWS development and implementation, and 2) Strengths and positive effects of the EWS development and implementation. The themes are shown in Figure 1.
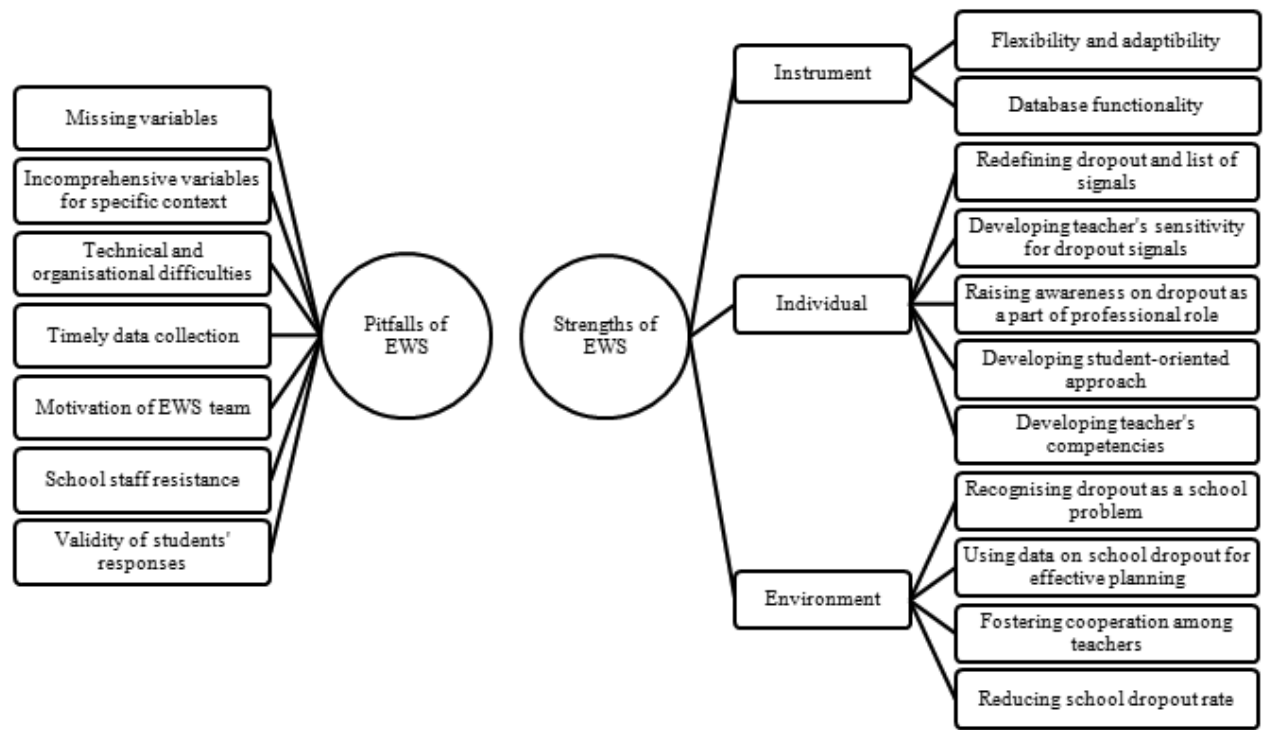

Figure 1. Thematic network identified from a thematic analysis of school and mentor reports.

The pitfalls of the EWS development and implementation

This theme describes a broad range of difficulties the EWS teams encountered during the process of the EWS development and implementation. It comprises seven subthemes related to the content of the the ISRD, organisational and technical difficulties in its implementation and the low motivation of different stakeholders to engage in building the EWS.

The process of implementation in one of the schools proved the importance of the EWS team motivation to be engaged, suggesting that the members should be chosen carefully.

The team perceived their engagement and work with students as additional and burdensome. The delays in the implementation of activities were excused by the claims that school staff was not paid enough by the state. (Final mentor report, School 5)

The most frequently cited barrier was school staff resistance. Mainly, this was the case with class teachers who are an important part of the EWS, 
since they are both the source of data on students and the creators and providers of support. Their resistance was mainly caused by the perception that data collection and development of interventions were useless and time demanding, as well as that dealing with dropout was not part of their professional role. In some schools, school staff expressed not only resistance towards implementing the instrument, but also towards their colleagues from the EWS team.

The study also indicated the importance of the school principal's support, especially since the members of the EWS team did not have access to all the data they needed for identification of students at risk. Also, the EWS team recognised that the proposed methodology did not include all relevant variables or categories of variables relevant for identification of students at risk of dropping out.

The data on parents' employment status are not sensitive enough. They do not include the category of individual agricultural entrepreneurs or those working abroad. (Feedback on instrument usefulness, School 2)

The EWS encouraged class teachers to get to know their students better at the beginning of the school year, but it produced some difficulties as well, such as an inability to address the dynamic signals, for instance, the changes in behaviour and decrease in achievements, and the lack of class teacher's knowledge about first-grade students in this part of the school year. Moreover, the static nature of the ISRD was recognised as contradictory with the fluid and on-going nature of the dropout phenomenon.

Another concern expressed by the EWS teams and class teachers was related to the validity of students' responses. The most frequently mentioned reasons were the low motivation of students to participate, low level of their functional literacy, as well as fishing for attention.

However, the contradictions between students' and teachers' responses proved to be a fruitful starting point for the following phases of the research.

Strengths and positive effects of the EWS development and implementation

Adaptability of the ISRD and functionality of the database are its major strengths. Adaptability refers to the possibility to tailor the instrument to fit the specific context - to redefine the instrument variables, add new variables and implement them in the most suitable way for the specific school. Functionality portrays the possibility of continuous update, using the data from the database as a starting point for the discussion on a specific student and monitoring the progress, following students at risk longitudinally and informing school staff on the dropout rate and the steps the school has taken to deal with it. 
The EWS teams' report increased the awareness of dropout and dropout signals, the changes in teachers' definitions of their professional roles and the development of their competencies. In this process, the members of the EWS team gained confidence and expertise, not just in dropout prevention, but also in introducing change to the school.

The EWS teams and mentors strove to jointly build a definition of dropout and early warning signals through comparing and contrasting the cases from their experience but gradually internalizing them and developing sensitivity towards these signals.

This is the school with a high incidence of early pregnancies. And three more groups are at higher risk of dropout: 1) children with low parental control, 2) students that have a lot of agricultural work in the family, which is the priority over school and learning, 3) three-year educational profile of tractor drivers is the most vulnerable since it is usually attended by students from extremely low socio-economic status families, and student travellers, at the same time. (Mentor report 3, School 1)

The study also revealed importance of empirical data as a basis for reflectively improving practices. The data were used as a starting point for discussions on a specific student, enabling teachers to get diverse perspectives on the student and a better idea on what a meaningful intervention would be. Moreover, dealing with dropout gradually became part of teachers' professional role, while signals became the lenses through which they observed their own practice.

The teachers learned to collect information, interpret it, and weigh the competing interpretations of the practical problem they started with. Both the process of doing research and the resulting products provided important learning for all team members.

Through the process of planning activities, as well as observing and recording everything we have done, we have developed competencies for evidence based decision making. (Final school report, School 3)

Therefore, based on teachers' own words and actions regarding the EWS and their involvement in the research, one can say that they viewed this experience as collaboration with their full participation, on the one hand, and systematic support and exchange of ideas, on the other.

The changes at the environment level portray different stages of building the EWS, from raising awareness of the dropout issue as a school problem and using the collected data for advocating the importance of dealing with dropout and developing effective intervention activities to reducing dropout as a consequence. Through continuous informing of school staff on the dropout rate, its causes and effects, the EWS teams put forth the issues of 
dropping out and dropout prevention as school problems. Such data-sharing promotes a reflective conversation and is at the heart of any transformation of the professional culture (Elliott, 1991).

At the school level, we have developed an expectation that all class teachers are responsible for dropout prevention. (Final school report, School 3)

As Avgitidou (2009) stated, the systematic recording of practice allowed the teachers to pose concerns, suggest ideas, support their actions and take an active advocacy role in the process of introducing change.

It is much easier for me now, when I have the data, to advocate for dropout reduction activities. (EWS team coordinator, School 1)

The collected data became school ownership and a basis for developing interventions at the level of the individual student, the group of students and school.

Cooperation among teachers was a pervasive issue, both as a difficulty and as strength. Having in mind the design of the EWS, it is clear that cooperation among teachers is considered to be a prerequisite for building the EWS at the school level. Through the process, we also learned that participation in the process as a member of a collaborative research team was powerful means for teachers to establish better collegial relations with other teachers (Lieberman, 1986).

\section{The Revision Phase}

During the revision phase, based on the previously presented data, the methodology for identification of students at risk was modified and adjusted to the specificities of each school's context. One of the indicators of success of the collaborative approach was the willingness of all five schools participating in the project to continue using the modified EWS.

Through the discussions between EWS teams and mentors/researchers dealing with the students identified as students at risk based on the ISRD, we found that the ISRD was overestimating the risk of dropping out. Therefore, we revised the thresholds, and the variation of one standard deviation was considered as moderate risk, while the variation of two standard deviations or more was considered a high risk of dropout. Furthermore, the teachers suggested revising the signal of low achievement at the end of the evaluation period, with one unsatisfactory mark being labelled as risk level one, and several unsatisfactory marks being labelled as risk level two (Table 2, the column named "Modified threshold").

The revision of signal definition and thresholds resulted in narrowing the general risk from the previously registered $55 \%$ to $30 \%$ of the student sample. To validate the revised proposal of signals and thresholds, we explored in 
more detail the status of 12 students that dropped out from the sample on the ISRD. The data showed that 10 students who dropped out were under the risk level 1 and two students were under the risk level 2, which suggests that the instrument was not underestimating the risk. This raises another important question on the reasons why the majority of students who dropped out were recognised as students under moderate risk. We could hypothesise that the students at moderate levels of risk were a blind spot for the EWS teams, since they focused their attention and support towards the students who were recognised as at higher risk of dropping out. Notwithstanding, the results show that, during the project, the dropout rate among the first grade students in our sample was $2.5 \%$, compared to $10.2 \%$ dropout rate in the school year preceding the project.

Moreover, based on the qualitative data from the observation and reflection phase, the schools have developed procedures for early identification of students at risk of dropping out, which includes informing class teachers on dropout importance and the signals of dropout, the guidelines for data collection and use of collected data on the level of class teachers, the EWS team and school. Although they have some steps in common, the procedures are developed to fit the characteristics of the specific school context.

\section{Discussion}

It is fairly obvious that holistic and collaborative approaches to early school leaving are needed (European Commission, 2013) to overcome the gap between inclusive, learner-centred orientation and the reality in education. It is recognised that one of the fruitful measures in this regard is work on developing the tools/instruments aiming to enhance school practices, which also makes a strong basis for sustainable interventions (Ainscow et al., 2004).

The development of the tool for early identification of students at risk of dropping out raised teachers' awareness of signals and made them incorporate the identification practices in their everyday work. Moreover, it allowed the development of interventions which are more localised, focused on the individual circumstances of particular teachers and schools, and rooted in the considerations of teachers' learning and practice (Darling-Hammond et al., 2003). The bottom-up approach to building the EWS, based on practitioners experience and knowledge, enables the school to gradually take over the ownership of the problem and the activities that were developed in order to solve the problem. The mentors had an important role in encouraging the teams' reflection on their previous experience, questioning of the existing practice and developing the new one, as well as in bridging theory and practice. The EWS teams and schools differed in how they coped with the difficulties which suggested the importance of taking into account specific strengths and 
needs of the context when developing changes. The effectiveness of the EWS, recognised in, among other things, reduced dropout rate, brought teachers' self-efficacy in dealing with dropout, and created the perception of school's benefits from building and improving the EWS.

Building the EWS as a response to dropout at school level enabled the school to develop evidence based activities, to monitor their implementation and adjust them timely. Moreover, the systematic approach forced schools and teachers to redefine their professional roles, as well as to coordinate them in order to prevent students from dropping out. Namely, in this context, professional accountability for the outcome is a demand on all actors, including the school leadership (Elmore, 1996).

Collaborative approach to the development of the early warning system for identification of students at risk of dropping out proved to be fruitful solution, since it favours the plurality of values, roles, goals, goods and authorities and brings voices to specific contexts and communities (Atkins \& Wallace, 2012; Fulan, 2005). CAR recognises expertise and interdependence of both practitioners and researchers, and, at the same time, offers an opportunity for learning for all the included actors. Both researchers and practitioners had an opportunity to affect the decisions made in each phase of the process and to contribute with their own expertise. This autonomy in decision making, together with the findings on increased awareness of dropout and dropout signals, the changes in teachers' definitions of their professional roles and development of competencies, shows that CAR is also a professional development tool. Namely, the collaboration opens up the opportunity for practitioners to assume new roles and exhibit leadership, giving legitimacy to school professionals' practical understanding and their definition of problems (Lieberman, 1986). In a climate where social status of the teaching profession is fairly low, as it is in Serbia, collaborative participation in educational research may provide an important stimulant in the form of recognition of teacher's professional worth and value.

\section{References}

Ainscow, M., Booth, T. \& Dyson, A. (2004). Understanding and developing inclusive practices in schools: a collaborative action research network. International Journal of Inclusive Education, 8, 125-139.

Alexander, K. L., Entwisle, D. R. \& Horsey, C. S. (1997). From First Grade Forward: Early Foundations of High School Dropout. Sociology of Education, 70, 87-107.

Allensworth, E. \& Easton, J. (2007). What Matters for Staying On-Track and Graduating in Chicago Public High Schools. Chicago: Consortium on Chicago School Research, University of Chicago.

Atkins, L. \&Wallace, S. (2012). Qualitative research in education. London: Sage. 
Atweh, B., Kemmis, S. \& Weeks, P. (1998). Action Research in Practice: Partnership for Social Justice in Education. London: Routledge.

Avgitidou, S. (2009). Participation, roles and processes in a collaborative action research project: a reflexive account of the facilitator. Educational Action Research, 17, 585-600. https://doi.org/10.1080/09650790903309441

Braun, V. \& Clarke, V. (2006). Using thematic analysis in psychology. Qualitative Research in Psychology, 3, 77-101. http://dx.doi.org/10.1191/1478088706qp063oa

Carr, W. \& Kemmis, S. (1986). Becoming Critical: Education, Knowledge and Action Research. London: Taylor \& Francis.

Darling-Hammond, L., Hightower, A. M., Husbands, J. L., LaFors, J. R., Young, V. M. \& Christopher, C. (2003). Building Instructional Quality: "Inside-Out" and "Outside-In" Perspectives on San Diego's School Reform. Washington: Center for the Study of Teaching and Policy, University of Washington.

Elliott, J. (1991). Action Research for Educational Change. Buckingham, UK: Open University Press. https://doi.org/10.1080/0141192930190510

Elmore, R. F. (1996). Accountability in local school districts: Learning to do the right things. In P. W. Thurston \& J. G. Ward (Eds.), Improving educational performance: Local and systemic reforms (59-82). Greenwich: JAI Press, Inc.

European Commission. (2013). Reducing early school leaving: Key messages and policy support. Final Report of the Thematic Working Group on Early School Leaving. Retrieved from http://ec.europa.eu/dgs/education_culture/repository/education/policy/strategic-framework/doc/esl-group-report_en.pdf

European Commission. (2014). Early warning systems in Europe: practice, methods and lessons. Retrieved from: http://ec.europa.eu/dgs/education_culture/repository/education/policy/strategic-framework/doc/europe-warning-systems_en.pdf

Fullan, M. (2005). Change theory as a force for school improvement. In J. M. Burger, C. F. Webber \& P. Klinck (Eds.), Intelligent Leadership: Constructs for Thinking Education Leaders (pp. 27-39). Dordrecht: Springer.

Helms, M. M. \& Nixon, J. (2010). Exploring SWOT analysis where are we now? A review of academic research from the last decade. Journal of Strategy and Management, 3, 215-251.

Jerald, C. (2006). Identifying potential dropouts: Key lessons for building an early warning data system. Washington: Achieve, Inc.

Jovanović, V., Čekić Marković, J., Veselinović, Ž., Vušurović, A., Jokić, T. (2016). Kako do škole društvene brige - studija o efektima mera prevencije i intervencije za sprečavanje osipanja učenika iz obrazovnog sistema Republike Srbije. Beograd: Centar za obrazovne politike.

Levin, H. M. (1986). Educational reform for disadvantaged students: An emerging crisis. West Haven: National Educational Association.

Lieberman, A. (1986). Collaborative research: Working with, not working on. Educational Leadership, 43, 28-32. Retrieved from http://www.researchgate.net/profile/Ann_Lieberman/publication/242108199_Collaborative_Research_Working_With_Not_Working_On/links/53fcb2120cf2dca8ffff4088.pdf

Parada, R. H. (2000). Adolescent Peer Relations Instrument: A theoretical and empirical basis for the measurement of participant roles in bullying and victimization of 
adolescence: An interim test manual and a research monograph: A test manual. Penrith South, Australia: Publication Unit, Self-concept Enhancement and Learning Facilitation (SELF) Research Centre, University of Western Sydney.

Pešikan, A. i Ivić, I. (2009).Obrazovanjem protiv siromaštva: analiza uticaja uvođenja pripremnog predškolskog programa u Srbiji. Beograd: Vlada Republike Srbije, Tim potpredsednikaVlade za implementaciju strategije za smanjenje siromaštva i Ministarstvo prosvete RS.

Pešikan, A. (2012). Obrazovna statistika u Srbiji: metodološki problemi. U A. Pešikan (Ur.), Osnovni resursi u preduniverzitetskom obrazovanju u Srbiji (str. 127-145). Beograd: Filozofski fakultet Univerziteta u Beogradu.

Pešikan. A. (2015). Preduniverzitetsko obrazovanje i vaspitanje u Srbiji: stanje, izazovi i pravci razvoja. U A. Kostić (Ur.), Obrazovanje - razvojni potencijal Srbije (str. 55-107). Beograd: Srpska akademija nauka i umetnosti.

Pešikan, A. (2016). Serbia: An overview. In T. Sprague (Ed.), Education in Non-EU Countries in Western and Southern Europe (pp. 247-269). London: Bloomsbury.

Rosenthal, B.S. (1998). Non-school correlates of dropout: An integrative review of the literature. Children and Youth Services Review, 20, 413-433.

Statistical Office of the Republic of Serbia (2011). Census. Book 3. Belgrade: Statistical Office of the Republic of Serbia.

Rumberger, R. W. (2001). Why students drop out of school and what can be done. Retrieved from https://escholarship.org/uc/item/58p2c3wp

Rumberger, R. W. (1987). High school dropouts: A review of issues and evidence. Review of educational research, 57(2), 101-121.

Stepanović Ilić, I., Videnović, M. i Lazarević, LJ. (2015).Odustajanje od školovanja: Analiza studija slučaja iz ugla ekološkog modela. Nastava i vaspitanje, 64, 453-468.

Statistical Office of the Republic of Serbia \& UNICEF (2014). Serbia Roma Settlements Multiple Indicator Cluster Survey (MICS 5). Preliminary results. Belgrade: Statistical Office of the Republic of Serbia and UNICEF.

Strategy of education development in Serbia 2020 (2012). Government of the Republic of Serbia.

Zuber-Skerritt, O. (1996). Emancipatory action research for organisational change and management development. In O. Zuber-Skerritt (Ed.), New directions in action research (pp. 83-105). London: Falmer Press. 


\section{Razvijanje sistema za rano prepoznavanje učenika koji su u riziku od osipanja iz obrazovnog sistema kroz saradničko akciono istraživanje}

\section{Olja Jovanović}

Univerzitet u Beogradu, Filozofski fakultet

\section{Ljiljana Plazinić}

Univerzitet u Beogradu, Učiteljski fakultet

\section{Jelena Joksimović}

Univerzitet u Beogradu, Filozofski fakultet

\section{Jovan Komlenac}

Gimnazija "Sava Šumanović", Šid

\section{Ana Pešikan \\ Univerzitet u Beogradu, Filozofski fakultet}

U radu su predstavljeni nalazi saradničkog akcionog istraživanja koje je imalo za cilj ispitivanje i opisivanje procesa izgradnje sistema za rano prepoznavanje i podršku učenicima koji su u riziku od osipanja iz obrazovnog sistema. Tokom jednog ciklusa, istraživanje je obuhvatilo faze planiranja, delovanja, posmatranja, refleksije i revizije. Sve faze su sprovedene kroz saradnju između nastavnika, stručnih saradnika i direktora iz pet poljoprivrednih i prehrambenih škola u Srbiji i tima istraživača. Tokom faze planiranja i delanja razvijen je i na uzorku od 485 učenika prvog razreda srednjih škola primenjen instrument za prepoznavanje učenika koji su u riziku od napuštanja školovanja. Prikupljeni podaci su korišćeni za razvoj odgovarajućih mera prevencije i intervencije za učenike kod kojih su registrovani neki od pokazatelja rizika od napuštanja škole. Opservacije koje se odnose na primenu predložene metodologije i refleksije na prikupljene podatke i procese su sistematski beležene kroz redovne mesečne sastanke između istraživača i zaposlenih u školama. Analiza 73 dokumenta koji su prikupljeni tokom faze posmatranja i refleksije je rezultirala sa 18 kategorija koje mogu biti grupisane dve široke teme - snage sistema i izazovi u razvoju i primeni sistema. Na osnovu nalaza iz prethodnih faza, predložena metodologija za prepoznavanje učenika koji su u riziku od napuštanja školovanja je revidirana, tako da odgovara na specifične snage i izazove svake od škola u uzorku. Istraživanje nudi dragocene uvide koji se odnose na razvoj izgradnje sistema za rano prepoznavanje i podršku učenicima koji su u riziku od osipanja iz obrazovnog sistema kroz saradnju između škola i istraživača.

Ključne reči: osipanje iz obrazovnog sistema, sistem za rano prepoznavanje i podršku, učenici u riziku od osipanja, saradničko akciono istraživanje 